\title{
Does hospital admission provide an opportunity for improving pharmacotherapy among elderly inpatients?
}

\author{
Daniela Oliveira de Melo ${ }^{1, *}$, Sílvia Storpirtis ${ }^{2}$, Eliane Ribeiro ${ }^{2,3}$ \\ ${ }^{I}$ Department of Biological Sciences, Institute of Environmental Sciences, Chemical and Pharmaceutical, Federal University \\ of São Paulo, São Paulo, ${ }^{2}$ Department of Pharmacy, College of Pharmaceutical Sciences, University of São Paulo, São Paulo, \\ ${ }^{3}$ University Hospital, University of São Paulo, São Paulo, Brazil
}

\begin{abstract}
The purpose of the work was to assess the incidence of potential drug interactions (pDDI), major pDDI, and the use of potentially inappropriate medication (PIM) at hospital admission, during hospitalization, and at discharge to evaluate whether hospital admission provides an opportunity for improving pharmacotherapy in elderly patients at a University hospital that has a clinical pharmacist. A prospective cohort study was carried out using data from the medical records of patients admitted to an internal medicine ward. All admissions and prescriptions were monitored between March and August 2006. Micromedex ${ }^{\circledR}$ DrugReax ${ }^{\circledR}$ and Beers Criteria 2015 were used to identify pDDI, major pDDI, and PIMs, respectively. A comparison of admission and discharge prescriptions showed the following: an increase in the proportion of patients using antithrombotic agents (76 versus 144; $\mathrm{p}<0.001$ ), lipid modifying agents (58 versus 81; $\mathrm{p}=0.024)$, drugs for acid-related disorders (99 versus $152 ; \mathrm{p}<0.001)$, and particularly omeprazole (61 versus $87 ; \mathrm{p}=0.015$ ); a decrease in the number of patients prescribed psycholeptics ( 73 versus 32 ; $\mathrm{p}<0.001$ ) and diazepam (54 versus $13 ; \mathrm{p}<0.001)$; and a decrease in the proportion of patients exposed to polypharmacy ( $16.1 \%$ versus $10.1 \%$; $\mathrm{p}=0.025)$, at least one $\mathrm{pDDI}(44.5 \%$ versus $32.8 \%$; $\mathrm{p}=0.002)$, major pDDI $(19.9 \%$ versus $12.2 \%$; $\mathrm{p}=0.010)$ or PIM ( $85.8 \%$ versus $51.9 \% ; \mathrm{p}<0.001)$. The conclusion is that admission to a hospital ward that has a clinical pharmacist was associated with a reduction in the number of patients exposed to polypharmacy, pDDI, major pDDI, and the use of PIMs among elderly inpatients.
\end{abstract}

Uniterms: Health Services/elderly patients. Internal Medicine/hospitals. Clinical Pharmacy. Drug interactions. Drug prescriptions.

\section{INTRODUCTION}

A general decline in global fertility rates, improvements in health conditions, increased income, and advancements in diagnostic and pharmaceutical technology have been associated with an increase in life expectancy and greater use of health services and medicines for the treatment of chronic and degenerative diseases. It is estimated that Brazil will have the sixth largest elderly population in the world by 2025 (OMS, 2005).

The impact of natural physiological changes on pharmacodynamic and pharmacokinetic drug processes has been correlated with an exaggerated or inappropriate response to medication or even an absence of health benefits for given drugs (Marengoni et al., 2011). These

*Correspondence: D. O. Melo. Universidade Federal de São Paulo. Instituto de Ciências Ambientais, Químicas e Farmacêuticas. Departamento de Ciências Biológicas. Av. Conceição, 329, 09920-000 - Diadema, SP, Brasil. E-mail: danimelofarmacia@gmail.com facts have aroused extensive concern about the appropriate use of medication in older patients.

Several factors contribute to adverse drug events (ADE) in the elderly, ranging from unnecessary drug use and inappropriate drug choice to the lack of long-term therapy reassessment, inadequate dosage regimens, and therapeutic duplication (AGS, 2015; Hubbard, O’Mahony, Woodhouse, 2013; Sichieri et al., 2013). In an attempt to prevent or at least minimize ADE in the elderly, many guides about potential ADE have been created to help clinicians choose the best therapeutic option. The most frequently used list for older adults is the Beer's List (AGS, 2015; Hubbard, O’Mahony, Woodhouse, 2013; Sichieri et al., 2013).

Adverse drug events are common and ADE prevention plays a significant role in patient safety, particularly among hospitalized patients. According to Pirmohamed et al. (2004), 1\% of all hospital admissions are caused by drug-drug interactions (DDIs), accounting for $16 \%$ of all hospital admissions due to adverse drug 
reactions (ADR) in United States (Pirmohamed et al., 2004). In the US, increased hospital costs associated with ADR were around $U \$ 4,700$ per admission, resulting in an annual estimated cost of $\$ 2$ billion to the country (Bates, 1995).

While the use of medication among the elderly is a conscious decision, research has shown that a total reduction in the use of prescription drugs would lead to a corresponding decrease in the incidence of ADE (Hubbard, O'Mahony, Woodhouse, 2013; Sichieri et al., 2013). Older people are major consumers of medications. The number of prescriptions for older patients is approximately 3.6 times times higher than that for younger adults and as such they are much more exposed to drug-related problems (Pasina et al., 2013). The use of multiple medications by a single patient (polypharmacy) has been associated with a higher incidence of potentially harmful drug interactions (Egger, Drewe, Schlienger, 2003; Marengoni et al., 2014; Vonbach et al., 2008).

Changes in drug therapy during hospital admission or discharge have been related to an increase in the use of prescription drugs, which leads to a greater likelihood of drug interactions (pDDI), which in turn may result in a higher prevalence of ADE (Grönroos et al., 1997; Smith et al., 1997; Vonbach et al., 2008). According to Vonbach et al. (2008), 47\% of all pDDI at hospital discharge were the result of medication changes during hospitalization. However, Laroche et al. (2006) demonstrated that the prescription of anticholinergic and inappropriate drugs among geriatric inpatients decreased at discharge, showing that hospitalization could provide an opportunity to reassess pharmacological treatment.

In 2009, Brazil's National Health Surveillance Agency (ANVISA, acronym in Portuguese) evaluated the influence of the pharmaceutical industry on the Brazilian health system. The resulting report showed that seven out of 10 public pharmacies did not have a supervising pharmacist (ANVISA, 2010). In a hospital setting, the constant presence of a pharmacist performing discharge planning and instructions is common, providing an important opportunity for therapy reassessment, particularly for elderly patients where the prevalence of multiple chronic conditions is generally high.

Potentially inappropriate medications are a concern among health professionals given the risk of adverse drug reactions and hospitalization among older adults (Endres et al., 2016). The need for educational interventions addressing the risks associated with given medications targeting doctors, pharmacists and patients themselves is increasingly recognized (Wahab, 2015).

This study therefore aims to investigate the incidence of potential drug-drug interactions and the use of potentially inappropriate medication (PIM) at hospital admission, during hospitalization, and at discharge in order to explore the association between hospitalization and improvements in pharmacotherapy among elderly patients admitted to an internal medicine ward at a public teaching hospital that has a regular clinical pharmacist.

\section{METHODS}

A prospective cohort study was carried out using data from the medical records of an internal medicine ward at a teaching hospital (the University Hospital of the University of São Paulo, Brazil). The University Hospital (UH) is a 256-bed public hospital that has a 44-bed adult internal medicine ward. The UH offers medium complexity clinical services to University students and the local community. All admissions (712) were followed during a six-month period (between March and August 2006), which generated 8,371 drug orders. The UH Pharmacy Service is centralized and, except for intravenous drugs, attends only inpatients through an individualized drug dispensing system. All prescriptions have to be reviewed by the clinical pharmacist before drug dispensing. Each clinic receives individualized patient medication from the pharmacy service for a maximum period of 24 hours.

The study included all patients aged over 60 years, who were classified as 'elderly'. Patients without drug orders who had been transferred to another ward or health care service and those for which the data was considered incomplete were excluded from the study sample. The following data was taken from the medical records: duration of hospital stay, patient identification (name, age, and sex), comorbidities (only those related to high blood pressure and diabetes mellitus, given the high prevalence of these conditions among the elderly and consequent chronic use of medications), and use of prescription drugs. After discharge, the primary diagnosis according to the ICD-10 classification was recorded as described in the discharge summary. The names of the prescribed and administered drugs, confirmed based on the signature of the head nurse on the patients' prescriptions, were recorded for each day of the patients' stay at hospital. The daily prescription includes all drugs administered during a patient's hospital stay regardless of the route or frequency of administration, formulary status, or whether they were prescribed once as an additional drug or as a regular routine order. The drugs were classified using the Anatomical Therapeutic Chemical (ATC) classification system.

The profile of drug utilization and polypharmacy were described. Since the concept of polypharmacy is unclear, the number of patients using four, five and nine 
different drugs was measured. Drug orders including two or more drugs were evaluated based on potential drugdrug interactions (pDDI), determined and classified using the Micromedex's DrugReax ${ }^{\circledR}$ software (Micromedex, 2014) according to severity (major, moderate and minor) and scientific documentation categories (excellent, good, fair, poor, or unlikely). Only pDDI with excellent and good documentation were classified as well documented, while those classified as poor or unlikely were excluded.

All pDDI during hospitalization were identified in order to measure the cumulative incidence of major and moderate pDDI among patients (total number of patients exposed to at least one pDDI divided by total number of patients). The incidence of pDDI at patient admission and discharge was also measured.

Potentially inappropriate medications were classified according to their appropriateness for elderly patients. This classification identifies patterns of drug use that unnecessarily place the elderly at risk of adverse drug events. The theoretical classification in this study was conducted independently from the diagnosis based on the updated Beers Criteria (AGS, 2015), except for the use of sliding scale insulin, which was not on the Beers list at the time of the study. The frequency of the use of inappropriate drugs among the elderly according to the Beers Criteria published in 2003 and 2012, both independent of diagnosis, have also been described (Fick et al., 2003).

The patients' demographic and prescription data were presented as mean, median, and standard deviation expressed as percentage, using Microsoft Excel ${ }^{\circledR}$ version 2007. The Shapiro-Wilks test was used to determine the normality of data. The chi-square test, Fisher's exact test, and t-test were also performed.

The research project was approved by the local ethics committee and registered in the National Information System on Ethics in Research Involving Human Beings (Sistema Nacional de Informação sobre Ética em Pesquisa envolvendo Seres Humanos - SISNEP; CAAE $\mathrm{n}^{\mathrm{o}}$ 0024.0198.018-07).

\section{RESULTS}

A total of 712 elderly patients were admitted to the internal medicine ward of the UH During the study period, 316 of which met the inclusion criteria, resulting in the evaluation of 2,954 drug orders. Table I shows the demographic and clinical characteristics of the patients.

A comparison of prescription drug use on admission and discharge showed that there was a reduction in the number of patients using psycholeptics (73 versus
TABLE I - Demographic and clinical characteristics of elderly patients admitted to the HU-USP between March and August 2006

\begin{tabular}{lc}
\hline Total number of patients & $\mathbf{3 1 6}$ \\
\hline Female & $162(51.3 \%)$ \\
Average age $\pm \mathrm{SD}$, years & $73.70 \pm 8.59$ \\
Blood pressure, $\mathrm{n}(\%)$ & $164(51.9 \%)$ \\
Diabetes, $\mathrm{n}(\%)$ & $67(21.2 \%)$ \\
Average length of stay $\pm \mathrm{SD}$, days & $11.61 \pm 9.57$ \\
The most frequent discharge diagnoses, $\mathrm{n}(\%)$ & \\
Bronchopneumonia & $73(23.1 \%)$ \\
Acute myocardial infarction & $43(13.6 \%)$ \\
Cerebrovascular accident & $15(4.7 \%)$ \\
Congestive heart failure & $11(3.5 \%)$ \\
\hline
\end{tabular}

$32 ; \mathrm{p}<0.001)$ and an increase in the number using antithrombotic agents ( 76 versus $144 ; p<0.001)$, drugs for acid-related disorders (99 versus 152; $<<0.001$ ), and lipid-modifying agents ( 58 versus $81 ; \mathrm{p}=0.024$ ).

A set of 219 different prescription drugs were distributed throughout 13 ATC codes. Ten $(4.6 \%)$ of these drugs could not be analyzed in relation to pDDI because they were not part of Micromedex's DrugReax ${ }^{\circledR}$ database drugs list: benserazide, bromopride, cloxazolam, etoricoxib, fenoterol, lanatoside $\mathrm{C}$, levomepromazine, metamizole, pericyazine, and salbutamol.

The mean number of prescription drugs, level of polypharmacy, pDDI and/or potentially inappropriate medication (PIM) at admission, during hospitalization, and at discharge among patients and orders are described in Table II.

Table III summarizes the most frequent well documented and major pDDI observed in the evaluated drug orders, while the PIMs are described in Table IV.

\section{DISCUSSION}

The findings regarding mean age and length of hospital stay corroborate previous studies conducted in internal medicine wards at teaching hospitals in Brazil (Marusic et al., 2013; Passarelli, Jacob-Filho, Figueras, 2005).

Cardiovascular diseases are common among Brazil's general population and comprise a substantial portion of hospital admissions in the country, followed by respiratory diseases, excluding obstetric admissions (Brasil, 2015). Since this study was conducted during the winter months, it is consistent that bronchopneumonia was the most 
TABLE II - Mean number of prescription drugs, polypharmacy, patients exposed to potential drug interactions (pDDI) and/or potentially inappropriate medication (PIM) according Beers Criteria published in 2003, 2012, and 2015 in drug orders at admission, during hospitalization, and at discharge, HU-USP, between March and August 2006

\begin{tabular}{|c|c|c|c|c|c|c|c|}
\hline & & $\begin{array}{l}\text { Hospital } \\
\text { Admission } \\
\text { (HA) }\end{array}$ & $\begin{array}{c}\text { During } \\
\text { hospitaliza- } \\
\text { tion } \\
\text { (DH) }\end{array}$ & $\begin{array}{c}\text { Hospital } \\
\text { Discharge } \\
\text { (HD) }\end{array}$ & $\begin{array}{c}\text { HA } \\
\text { versus } \\
\text { DH } \\
\text { p }\end{array}$ & $\begin{array}{c}\text { DH } \\
\text { versus } \\
\text { HD } \\
\text { p }\end{array}$ & $\begin{array}{c}\text { HA } \\
\text { versus } \\
\text { HD } \\
\text { p }\end{array}$ \\
\hline $\begin{array}{l}\text { Number of } \\
\text { drugs }\end{array}$ & $\begin{array}{l}\text { Mean number } \\
\text { of prescription } \\
\text { drugs } \pm \mathrm{SD}\end{array}$ & $5.73 \pm 2.92$ & $6.25 \pm 2.82$ & $4.36 \pm 2.99$ & $<0.001^{\text {a }}$ & $<0.001^{a}$ & $<0.001^{\text {a }}$ \\
\hline \multirow[t]{3}{*}{ Polypharmacy } & $\begin{array}{l}\text { Patients that } \\
\text { received a } \\
\text { minimum of } \\
4 \text { prescription } \\
\text { drugs, n }(\%)\end{array}$ & $174(55.1 \%)$ & $226(71.5 \%)$ & $162(51.3 \%)$ & $<0.001^{\text {b }}$ & $<0.001^{b}$ & $0.339^{\mathrm{b}}$ \\
\hline & $\begin{array}{l}\text { Patients that } \\
\text { received a } \\
\text { minimum of } \\
5 \text { prescription } \\
\text { drugs, } \mathrm{n}(\%)\end{array}$ & $147(46.5 \%)$ & $188(59.5 \%)$ & $126(39.9 \%)$ & $<0.001^{\mathrm{b}}$ & $<0.001^{b}$ & $0.092^{b}$ \\
\hline & $\begin{array}{l}\text { Patients that } \\
\text { received a } \\
\text { minimum of } \\
9 \text { prescription } \\
\text { drugs, n }(\%)\end{array}$ & $51(16.1 \%)$ & $77(24.4 \%)$ & $32(10.1 \%)$ & $<0.001^{b}$ & $<0.001^{\mathrm{b}}$ & $0.025^{b}$ \\
\hline \multirow[t]{2}{*}{ pDDI } & $\begin{array}{c}\text { Exposed to at } \\
\text { least one pDDI, } \\
\mathrm{n}(\%)\end{array}$ & $141(44.5 \%)$ & $247(78.2 \%)$ & $104(32.8 \%)$ & $<0.001^{\mathrm{b}}$ & $<0.001^{\mathrm{b}}$ & $0.002^{b}$ \\
\hline & $\begin{array}{l}\text { Exposed to at } \\
\text { least one major } \\
\text { pDDI, n }(\%)\end{array}$ & $63(19.9 \%)$ & $159(50.3 \%)$ & $39(12.2 \%)$ & $<0.001^{\text {b }}$ & $<0.001^{\mathrm{b}}$ & $0.010^{b}$ \\
\hline PIM (2003) & $\begin{array}{l}\text { Exposed to at } \\
\text { least one PIM, } \\
\mathrm{n}(\%)\end{array}$ & $78(24.7 \%)$ & $153(48.4 \%)$ & $57(18.0 \%)$ & $<0.001^{\text {b }}$ & $<0.001^{\mathrm{b}}$ & $0.041^{\mathrm{b}}$ \\
\hline PIM (2012) & $\begin{array}{l}\text { Exposed to at } \\
\text { least one PIM, } \\
\mathrm{n}(\%)\end{array}$ & $123(38.9 \%)$ & $188(59.5 \%)$ & $92(29.1 \%)$ & $<0.001^{b}$ & $<0.001^{b}$ & $0.009^{b}$ \\
\hline PIM (2015) & $\begin{array}{c}\text { Exposed to at } \\
\text { least one PIM, } \\
\mathrm{n}(\%)\end{array}$ & $271(85.8 \%)$ & $236(74.7 \%)$ & $164(51.9 \%)$ & $<0.001^{b}$ & $<0.001^{b}$ & $<\mathbf{0 . 0 0 1}^{\mathrm{b}}$ \\
\hline
\end{tabular}

Key: $\mathrm{SD}=$ Standard Deviation $-{ }^{\mathrm{a}}=$ test-t; ${ }^{\mathrm{b}}=$ chi-square test

frequently reported diagnosis. Bronchopneumonia, acute myocardial infarction, stroke, and heart failure are also documented as a frequent cause of hospitalization by other studies (Marusic et al., 2013; Passarelli, Jacob-Filho, Figueras, 2005).

The mean number of prescription drugs and number of patients exposed to at least nine drugs, one pDDI, major pDDI or PIM decreased during hospitalization in comparison. This finding reinforces the hypothesis that hospital admission can provide an opportunity to improve pharmacotherapy among the elderly when health professionals are aware of these factors and/or have support. The number of parameters increased during hospitalization - this is to be expected due to poorer health. A recently published study performed in a Norwegian hospital with 232 older adults ( $>75$ years) observed that, apart from a significant decrease in the prescription of anticholinergics and benzodiazepines, the 
TABLE III - Profile of the ten most frequent major and well documented potential drug interactions that the patients were exposed to during hospitalization in HU-USP between March and August 2006

\begin{tabular}{|c|c|c|c|c|c|c|c|}
\hline Drug & Drug & $\begin{array}{c}\text { Hospital } \\
\text { Admission } \\
\text { (HA) }\end{array}$ & $\begin{array}{c}\text { During } \\
\text { hospitalizati- } \\
\text { on } \\
\text { (DH) }\end{array}$ & $\begin{array}{c}\text { Hospital } \\
\text { Discharge } \\
\text { (HD) }\end{array}$ & $\begin{array}{c}\text { HA } \\
\text { versus } \\
\text { DH } \\
\text { p }\end{array}$ & $\begin{array}{c}\text { DH } \\
\text { versus } \\
\text { HD } \\
\text { p }\end{array}$ & $\begin{array}{c}\text { HA } \\
\text { versus } \\
\text { HD } \\
\text { p }\end{array}$ \\
\hline $\begin{array}{l}\text { Anticoagulants } \\
\text { or antiplatelet } \\
\text { drugs }\end{array}$ & Any drug & $64(20.2 \%)$ & $156(49.4 \%)$ & $131(41.4 \%)$ & $<0.001^{\text {a }}$ & $0.046^{\mathrm{a}}$ & $<0.001^{\mathrm{a}}$ \\
\hline Anticoagulant & Antiplatelet & $32(10.1 \%)$ & $110(34.8 \%)$ & $95(30.1 \%)$ & $<0.001^{\text {a }}$ & $0.202^{\mathrm{a}}$ & $<0.001^{\mathrm{a}}$ \\
\hline Aspirin & Heparin & $0(0.0 \%)$ & $91(28.8 \%)$ & $0(0.0 \%)$ & $<0.001^{\mathrm{b}}$ & $<0.001^{\mathrm{b}}$ & $>0.999^{b}$ \\
\hline Aspirin & Warfarin & $2(0.6 \%)$ & $14(4.4 \%)$ & $1(0.3 \%)$ & $0.003^{b}$ & $0.001^{\mathrm{b}}$ & $0.623^{\mathrm{b}}$ \\
\hline Heparin & Warfarin & $0(0.0 \%)$ & $7(2.2 \%)$ & $0(0.0 \%)$ & $0.015^{\mathrm{b}}$ & $0.015^{\mathrm{b}}$ & $>0.999^{\mathrm{b}}$ \\
\hline Clopidogrel & Omeprazole & $8(2.5 \%)$ & $16(5.1 \%)$ & $16(5.1 \%)$ & $0.144^{b}$ & $>0.999^{\mathrm{b}}$ & $0.144^{\mathrm{b}}$ \\
\hline Captopril & Spironolacton & $3(0.9 \%)$ & $12(3.8 \%)$ & $8(2.5 \%)$ & $0.033^{b}$ & $0.496^{\mathrm{b}}$ & $0.222^{\mathrm{b}}$ \\
\hline Captopril & $\begin{array}{l}\text { Potassium } \\
\text { chloride }\end{array}$ & $0(0.0 \%)$ & $6(1.9 \%)$ & $0(0.0 \%)$ & $0.030^{\mathrm{b}}$ & $0.030^{\mathrm{b}}$ & $>0.999^{b}$ \\
\hline Ciprofloxacyn & Insulin & $0(0.0 \%)$ & $7(2.2 \%)$ & $0(0.0 \%)$ & $0.015^{\mathrm{b}}$ & $0.015^{\mathrm{b}}$ & $>0.999^{b}$ \\
\hline Simvastatin & Warfarin & $4(1.3 \%)$ & $9(2.8 \%)$ & $9(2.8 \%)$ & $0.262^{b}$ & $>0.999^{b}$ & $0.262^{b}$ \\
\hline
\end{tabular}

Key: ${ }^{\mathrm{a}}=$ chi-square test $-{ }^{\mathrm{b}}=$ Fisher's exact test

TABLE IV - Description of potentially inappropriate medication prescribed for elderly inpatients of the UH between March and August 2006 according the Beers Criteria published in 2015

\begin{tabular}{|c|c|c|c|c|c|c|c|}
\hline Drug & Associated risk & $\begin{array}{c}\text { Hospital } \\
\text { Admission } \\
\text { (HA) } \\
\text { n (\%) }\end{array}$ & $\begin{array}{c}\text { During } \\
\text { hospitalization } \\
\text { (DH) } \\
\text { n (\%) }\end{array}$ & $\begin{array}{l}\text { Hospital } \\
\text { Discharge } \\
\text { (HD) } \\
\text { n (\%) }\end{array}$ & $\begin{array}{c}\text { HA } \\
\text { versus } \\
\text { DH } \\
\text { p }\end{array}$ & $\begin{array}{c}\text { DH } \\
\text { versus } \\
\text { HD } \\
\text { p }\end{array}$ & $\begin{array}{c}\text { HA } \\
\text { versus } \\
\text { HD } \\
\text { p }\end{array}$ \\
\hline \multicolumn{8}{|l|}{ Anticholinergics } \\
\hline $\begin{array}{l}\text { Dexchlorphenira- } \\
\text { mine }\end{array}$ & $\begin{array}{c}\text { Potent } \\
\text { - anticholinergic } \\
\text { effects, prolonged } \\
\text { sedation }\end{array}$ & $15(4.7 \%)$ & $2(0.6 \%)$ & $3(0.9 \%)$ & $0.002^{\mathrm{a}}$ & $0.686^{\mathrm{a}}$ & $0.004^{\mathrm{a}}$ \\
\hline Promethazine & $\begin{array}{c}\text { Potent } \\
\text { anticholinergic } \\
\text { effects, prolonged } \\
\text { sedation }\end{array}$ & $10(3.2 \%)$ & $2(0.6 \%)$ & $3(0.9 \%)$ & $0.037^{\mathrm{a}}$ & $0.686^{\mathrm{a}}$ & $0.089^{\mathrm{a}}$ \\
\hline \multicolumn{8}{|l|}{ Antispasmodics } \\
\hline \multicolumn{8}{|l|}{ Cardiovascular } \\
\hline Amiodarone & $\begin{array}{c}\text { Changes } \\
\text { in the QT } \\
\text { interval, severe } \\
\text { arrhythmias, such } \\
\text { as torsades de } \\
\text { pointes }\end{array}$ & $28(8.9 \%)$ & $16(5.1 \%)$ & $14(4.4 \%)$ & $0.607^{\mathrm{b}}$ & $0.708^{\mathrm{b}}$ & $0.254^{\mathrm{b}}$ \\
\hline
\end{tabular}


TABLE IV - Description of potentially inappropriate medication prescribed for elderly inpatients of the UH between March and August 2006 according the Beers Criteria published in 2015 (cont.)

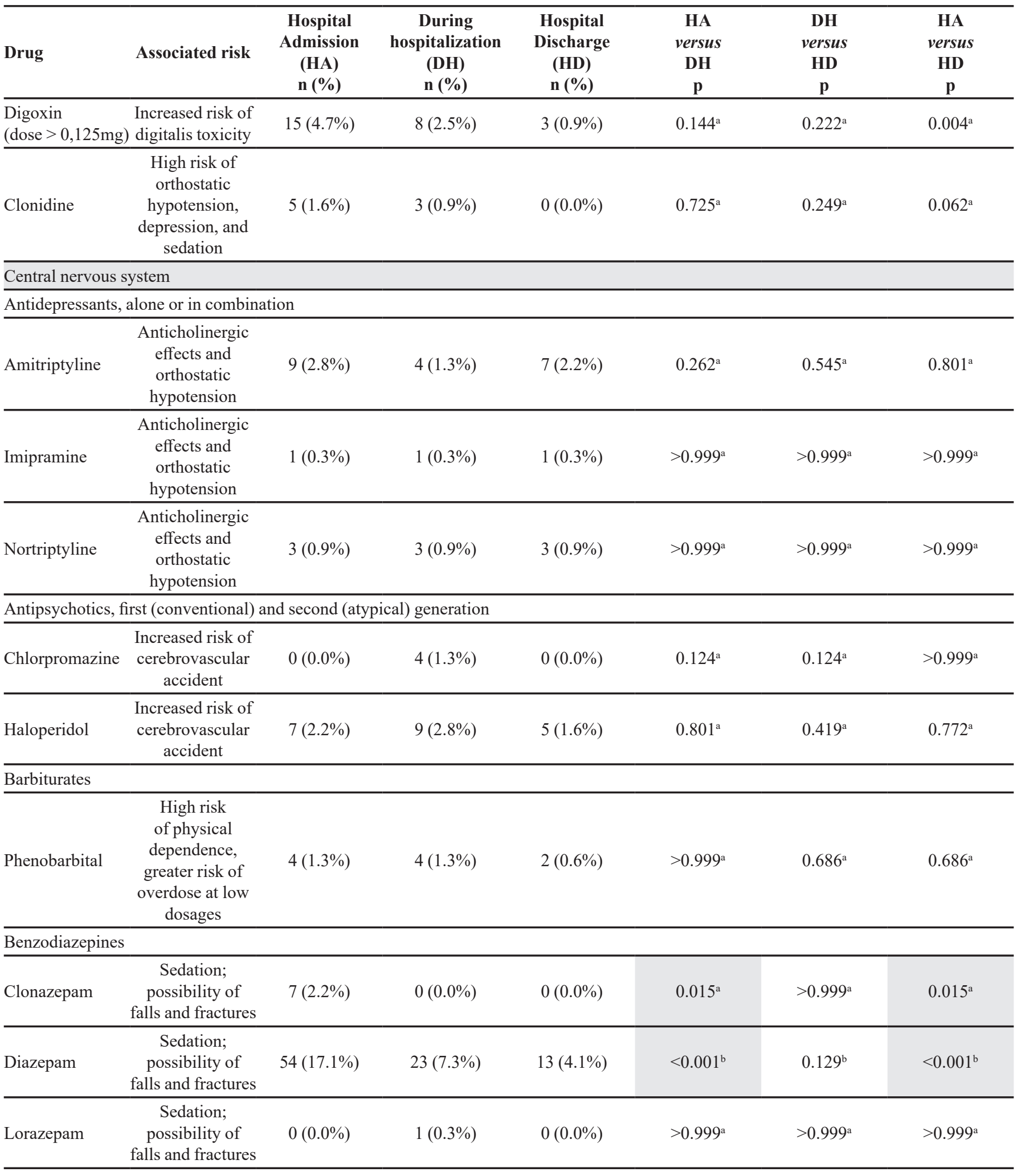


TABLE IV - Description of potentially inappropriate medication prescribed for elderly inpatients of the UH between March and August 2006 according the Beers Criteria published in 2015 (cont.)

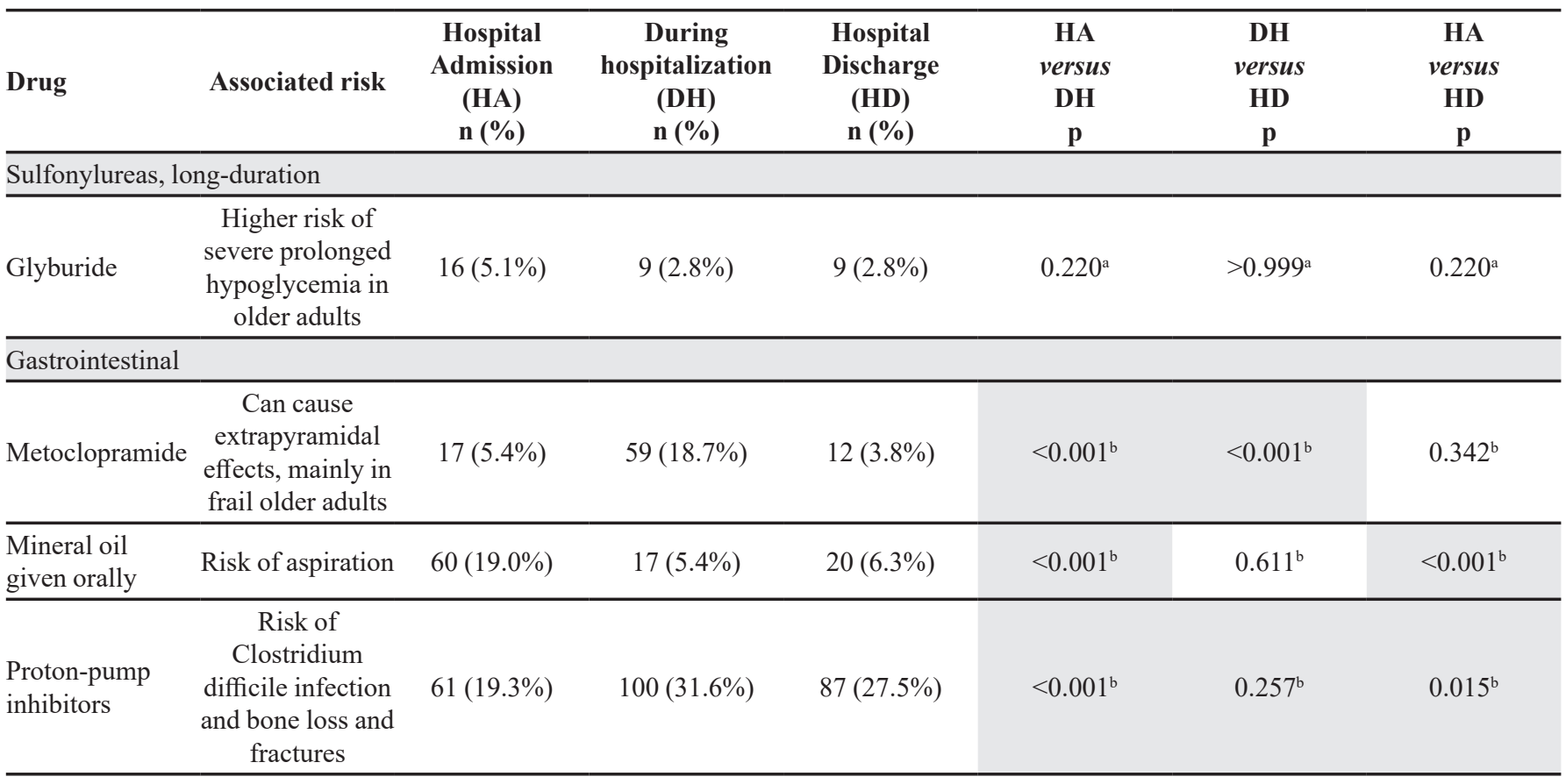

Key: ${ }^{\mathrm{a}}=$ Fisher's exact test $-{ }^{\mathrm{b}}=$ chi-square test

number of prescription drugs and prevalence of PIMs were not affected by hospitalization. The study used the Norwegian General Practice (NORGEP) criteria for PIM. The authors also found that the medication profile was more appropriate among elderly patients in the geriatric ward and a greater reduction of dosage and prescription of PIMs in comparison to other patients (Kersten et al., 2015).

Certain changes in drug prescription profiles were found before and after hospitalization, such as an increase in the proportion of patients using antithrombotic agents and lipid modifying agents due to the high prevalence of cardiovascular diseases. A reduction in the number of patients who were prescribed psycholeptics, mainly diazepam, was highlighted, as reported by the Norwegian study (Kersten et al., 2015). A prospective cohort study with patients aged 70 years and over in Australian hospitals investigated the use of benzodiazepines in acute care settings and explored the association with falls before (during a 90-day period prior to admission) and during hospitalization. Although no statistically significant difference was found between falls among users and nonusers of these drugs during hospitalization and prior to admission, a positive association was observed between history of falls and use of diazepam at admission when compared with all other benzodiazepine users (odds ratio 3.0; $95 \%$ CI 1.1-8.5; $\mathrm{p}=0.036$ ) (Ballokova et al., 2014).
On the other hand, an increase in the prescription of drugs for acid-related disorders, particularly protonpump inhibitors, was observed. The use of proton-pump inhibitors is common among patients treated with multiple drugs. According to a number of studies, the prescription of these drugs is inappropriate in 40 to $80 \%$ of patients (Ahrens, Behrens, Himmel et al., 2012). Although, in general, proton-pump inhibitors are well tolerated, it is important to note that they may cause clinically relevant drug interactions and their safety for long-term use remains unclear (Pilotto et al., 2010). Recent studies have suggested that there is an association between the prolonged use of proton-pump inhibitors and enteric infections caused by Clostridium Difficile, which increases the risk of community-acquired pneumonia and hip fractures (Pilotto et al., 2010; Thomson et al., 2010).

According to the literature, the incidence of pDDI is directly correlated with number of prescription drugs (Björkman et al., 2002; Cruciol-Souza, Thomson, 2006; Marusic et al., 2013; Passarelli, Jacob-Filho, Figueras, 2005; Secoli et al., 2010). Studies have shown that the number of prescription drugs, $\mathrm{pDDI}$, and the incidence of major pDDI were significantly lower at hospital discharge than at admission, which may be related to the lower number of prescription drugs. A study of a sample of outpatients also found that most patients $(82 \%)$ using five or more medications are more likely to be exposed 
to pDDI (Holbrook et al., 2005). A community study conducted in Brazil also revealed that the risk of pDDI is three times greater among older adults using five or more drugs (Secoli et al., 2010). Thus, the decrease in both pDDI and the incidence of major pDDI at discharge is consistent with a reduction in the total number of prescription drugs.

Most studies addressing the incidence of pDDI among the elderly were performed in outpatient health care services (Björkman et al., 2002; Gaeta et al., 2002; Obreli Neto et al., 2012; Secoli et al., 2010). An investigation involving six European countries reported that $46 \%$ of elderly outpatients had been exposed to at least one clinically relevant pDDI (Björkman et al., 2002). In Brazil, Secoli et al (2010) found that $54.9 \%$ of elderly outpatients who use two or more drugs had been exposed to at least one pDDI and that pDDI prevalence was $26.5 \%$ (Secoli et al., 2010). Other Brazilian studies observed that $15 \%$ of ADR in a public hospital were related to drug interactions (Passarelli, Jacob-Filho, Figueras, 2005) that $8 \%$ of elderly primary care patients had been exposed to some kind of pDDI, and that $6.5 \%$ of ADR were due to DDI (Obreli Neto et al., 2012).

The proportion of patients exposed to at least one pDDI or one major pDDI at admission was $44.5 \%$ and $19.9 \%$, respectively. A study conducted in 70 internal medicine and geriatric wards in Italy (total of 2,712 elderly patients) observed that 1,642 patients $(60.5 \%)$ had been exposed to one or more pDDI and 512 (18.9\%) to one severe pDDI at hospital admission (Pasina et al., 2013 ), while $85.6 \%$ of elderly patients ( 190 out of a total of 222) discharged from the internal medicine ward of a tertiary-level hospital in Croatia had been exposed to at least one pDDI (Marusic et al., 2013). Furthermore, $69.1 \%$ of patients discharged from an Italian hospital $(1,598$ out of a total of 2,314$)$ were exposed to at least one pDDI and $24.2 \%$ (561) to one severe pDDI (Pasina et al., 2013). Several studies have reported a larger number of pDDI and patients exposed to potentially severe DDIs at hospital discharge in comparison to admission (Egger, Drewe, Schlienger, 2003; Pasina et al., 2013; Vonbach et $a l ., 2008)$. Thus, it can be assumed that the exposure of elderly outpatients to ADE is the same as that of inpatients.

The pDDI and major pDDI profile observed by this study are common and to be expected in a hospital setting. Although a potential risk, they cannot be considered medication errors or contraindicated medications. In fact, most associations are routinely used to obtain better therapeutic results and only require patient monitoring. Available evidence regarding the association between antiplatelet and an anticoagulant drugs such as aspirin and heparin is not conclusive about the risks and benefits of combining anticoagulant and antiplatelet medications to reduce cardiovascular events. That is to say that there is no consensus about the harmful effects of combined use (Lane et al., 2013; Massel, Little, 2013). There is also considerable debate about the negative impact of the combined use of proton-pump inhibitors and clopidogrel, one of the most frequent major pDDI. Recently published reviews concluded that platelet function studies do not demonstrate a consistent interaction between clopidogrel and PPI. To date, studies have failed to determine the risk of adverse cardiovascular effects due to the heterogeneous nature of samples and methodology (Focks et al., 2013; Kwok, Loke, 2012). Furthermore, the concomitant administration of captopril and spironolactone or potassium supplements is one of the most frequently described major pDDI in both outpatients and inpatients (Obreli Neto et al., 2012). Although this combination may increase the risk of arrhythmias, the interaction is safe in a hospital setting where a potassium test is part of routine laboratory monitoring.

In Brazil, a study involving a sample of 186 elderly internal medicine inpatients and using Beers Criteria published in 2003 observed that 115 patients $(61.8 \%)$ were exposed to at least one ADR, principally (55.7\%) during hospitalization (Passarelli, Jacob-Filho, Figueras, 2005). The use of potentially inappropriate medication (PIM) leads to a two-fold increase in the risk of ADR. In addition, the use of PIMs was associated with a larger number of prescription drugs and adverse drug reactions (Passarelli, Jacob-Filho, Figueras, 2005).

Regarding length of hospital stay, 236 (74.7\%) elderly patients were exposed to at least one PIM. However, these results are not comparable with others studies due to changes in the Beers Criteria list in 2015. The main change to the last version of the list was the inclusion of proton-pump inhibitors, which has an impact on the results of this study. In fact, omeprazole was the only PIM whose prescription increased at discharge and was the most prescribed PIMs during and after hospitalization. Prevalence rates vary considerably across different studies involving inpatients: $5.3-40.7 \%$ in the USA, 16.3 - 52.6\% in Canada, $19.8 \%$ in Europe, and 38.5\% in Portugal (Curtis et al., 2004; Fialová et al., 2005; Maio, Del Canale, Abouzaid, 2010; Nyborg, Straand, Brekke, 2012; Oliveira Martins et al., 2006). In Brazil, prevalence rates range between $15.6 \%$ and $41 \%$ (Faustino, Passarelli, Jacob-Filho, 2013; Passarelli, Jacob-Filho, Figueras, 2005). However, it is important to take into account which version of the Beers Criteria was used in each analysis. The prevalence of PIMs at hospital admission and discharge was $85.8 \%$ and $51.9 \%$, respectively, However, it should 
be noted that these rates are influenced by the prescription of omeprazole. It is also important to note that it is often difficult to replacing certain PIMs because of the lack of availability of drugs in in São Paulo's primary healthcare service.

Limitations of this study include the fact that there are few comparable studies involving internal medicine wards and the wide range of prevalence of pDDI and PIMs due to contrasting methodologies used in the literature. In addition, several medications on the Beers Criteria list are unavailable in countries other than the United States, whereas a number of drugs sold in Brazil, including those observed in this study, are not listed. The high prevalence of pDDI and PIMs found by this study does not suggest an unsatisfactory level of prescribing quality since clinical decisions are made on an individual basis, considering the patient's medical condition and the hospital drug formulary.

\section{CONCLUSION}

The findings of this study suggest that the admission to hospital ward that has a clinical pharmacist may provide a good opportunity to review and adjust chronic disease therapy, especially among elderly inpatients. The close monitoring of inpatients during their stay in hospital enables the identification and solution of previously undetected problems that are often present in outpatients. However, quality health care services require a multidisciplinary environment that ensures the free flow of information between hospital physicians and general practitioners.

\section{ACNOWLEDGEMENTS}

The authors are grateful to the School of Pharmaceutical Sciences and the University Hospital of the University of São Paulo; São Paulo, Brazil, and to the Coordination for the Improvement of Higher Education Personnel (CAPES, acronym in Portuguese) for their financial support (application number 140956/2006-9).

\section{REFERENCES}

AGÊNCIA NACIONAL DE VIGILANCIA SANITÁRIA. ANVISA. Diagnóstico situacional da promoção de medicamentos em unidades de saúde do Sistema Único de Saúde (SUS) Brasília: Anvisa, 2010.
AHRENS, D.; BEHRENS, G.; HIMMEL, W.; KOCHEN, M.M.; CHENOT, J.F. Appropriateness of proton pump inhibitor recommendations at hospital discharge and continuation in primary care. Int. J. Clin. Pract., v.66, n.8, p.767-773, 2012.

AMERICAN GERIATRICS SOCIETY. AGS. American Geriatrics Society 2015 Updated Beers Criteria for Potentially Inappropriate Medication Use in Older Adults. J. Am. Geriatr. Soc., v.63, n.11, p.2227-2246, 2015.

BALLOKOVA A.; PEEL N.M.; FIALOVA D.; SCOTT, I.A.; GRAY, L.C.; HUBBARD, R.E. Use of benzodiazepines and association with falls in older people admitted to hospital: a prospective cohort study. Drugs Aging, v.31, n.4, p.299310, 2014.

BATES, D. W. Incidence of adverse drug events and potential adverse drug events. J. Am. Med. Assoc. Evid., v.274, n.1, p.29, 5 jul. 1995.

BJÖRKMAN, I. K.; FASTBOM, J.; SCHMIDT, I.K.; BERNSTEN, C.B.; PEER, G.P. Drug-drug interactions in the elderly. Ann. Pharmacother., v.36, n.11, p.1675-81, 2002.

BRASIL. DATASUS. Sistema de informações hospitalares. Disponível em: <www.datasus.gov.br.>. Acesso em: 20 de maio de 2015.

CAMPANELLI, C. M. American geriatrics society updated Beers criteria for potentially inappropriate medication use in older adults. J. Am. Geriatr. Soc., v.60, n.4, p.616-631, 2012.

CRUCIOL-SOUZA, J. M.; THOMSON, J. C. Prevalence of potential drug-drug interactions and its associated factors in a Brazilian teaching hospital. J. Pharm. Pharmac. Sci., v.9, n.3, p.427-33, 2006.

CURTIS, L.H.; ØSTBYE, T.; SENDERSKY, V.; HUTCHISON, S.; DANS, P.E.; WRIGHT, A.; WOOSLEY, R.L.; SCHULMAN, K.A. Inappropriate prescribing for elderly Americans in a large outpatient population. Arch. Intern. Med., v.164, n.15, p.1621-5, 2004.

EGGER, S. S.; DREWE, J.; SCHLIENGER, R. G. Potential drug-drug interactions in the medication of medical patients at hospital discharge. Eur. J. Clin. Pharm., v.58, n.11, p.773-8, 2003. 
ENDRES, H.G.; KAUFMANN-KOLLE, P.; STEEB, V.; BAUER, E.; BÖTTNER C.; THÜRMANN, P. Association between Potentially Inappropriate Medication (PIM) use and risk of hospitalization in older adults: an observational study based on routine data comparing the use of PIM with use of PIM alternatives. PLoS one, v.11, n.2, e0146811. doi:10.1371/journal.pone.0146811.

FAUSTINO, C. G.; PASSARELLI, M. C. G.; JACOB-FILHO, W. Potentially inappropriate medications among elderly Brazilian outpatients. São Paulo Med. J., v.131, n.1, p.1926, 2013.

FIALOVÁ, D.; TOPINKOVÁ, E.; GAMBASSI, G.; FINNESOVERI, H.; JÓNSSON, P.V.; CARPENTER, I.; SCHROLL, M.; ONDER, G.; SORBYE, L.W.; WAGNER, C.; REISSIGOVÁ, R.; BERNABEI, R. Potentially inappropriate medication use among elderly home care patients in Europe. JAMA Evid., v.293, n.11, p.1348-58, 2005.

FICK, D.M. ; COOPER, J.W. ; WADE, W.E. ; WALTER, J.L.; MACLENA, J.R. ; BEERS, M.H. Updating the Beers criteria for potentially inappropriate medication use in older adults. Arch. Intern. Med., v.163, n.22, p.2716-24, 2003.

FOCKS, J.J.; BROUWER, M.A.; VAN OIJEN, M.G.H.; LANAS, A.; BHATT, D.L.; VERHEUGT, F.W.A. Concomitant use of clopidogrel and proton pump inhibitors: impact on platelet function and clinical outcome- a systematic review. Heart, v.99, n.8, p.520-7, 2013.

GAETA, T.J.; FIORINI, M.; ENDER, K.; BOVE, J.; DIAZ, J. Potential drug-drug interactions in elderly patients presenting with syncope. J. Emerg. Med., v.22, n.2, p.15962, 2002.

GRÖNROOS, P.E.; IRJALA, K.M.; HUUPPONEN, R.K.; SCHEININ, H.; FORSSTRÖM, J.; FORSSTRÖM, J.J. A medication database--a tool for detecting drug interactions in hospital. Eur. J. Clin. Pharm.., v.53, n.1, p.13-7, 1997.

HOLBROOK, A.M.; PEREIRA, J. A.; LABIRIS, R.; MCDONALD, H.; DOUKETIS, J.D.; CROWTHER, M.; WELLS, P.S. Systematic overview of warfarin and its drug and food interactions. Arch. Intern. Med., v.165, n.10, p.1095-106, 2005.

HUBBARD, R. E.; O’MAHONY, M. S.; WOODHOUSE, K. W. Medication prescribing in frail older people. Eur. J. Clin. Pharm.., v.69, n.3, p.319-26, 2013.
KERSTEN, H.; HVIDSTEN, L.T.; GLØERSEN, G.; WYLLER, T.B.; WANG-HANSEN, M.S. Clinical impact of potentially inappropriate medications during hospitalization of acutely ill older patients with multimorbidity. Scand. J. Prim. Health Care, v.33, p.243-51, 2015.

KWOK, C.S.; LOKE, Y.K. Inconsistencies surrounding the risk of adverse outcomes with concomitant use of clopidogrel and proton pump inhibitors. Exp. Opin. Drug Saf., v.11, n.2, p.275-84, 2012.

LANE, D.A.; RAICHAND, S.; MOORE, D.; CONNOCK, M.; FRY-SMITH, A.; FITZMAURICE, D.A. Combined anticoagulation and antiplatelet therapy for high-risk patients with atrial fibrillation: a systematic review. Health Tech. Asses., v.17, n.30, p.1-188, 2013.

LAROCHE, M.-L.; CHARMES, J-P.; NOUAILLE, Y. FOURRIER, A. MERLE, L. Impact of hospitalization in an acute medical geriatric unit on potentially inappropriate medication use. Drugs \& Aging, v.23, n.1, p.49-59, 2006.

LIN, C.-F.; WANG, C.-Y.; BAI, C.-H. Polypharmacy, aging and potential drug-drug interactions in outpatients in Taiwan: a retrospective computerized screening study. Drugs \& Aging, v.28, n.3, p.219-25, 2011.

MAIO, V.; DEL CANALE, S.; ABOUZAID, S. Using explicit criteria to evaluate the quality of prescribing in elderly Italian outpatients: a cohort study. J. Clin. Pharm. Ther.., v.35, n.2, p.219-29, 2010.

MARENGONI, A.; ANGLEMAN, S.; MELIS, R.; MANGIALASCHE, F.; KARP, A.; GARMEN, A. ; MEINOW, B. ; FRATIGLIONI, L. Aging with multimorbidity: a systematic review of the literature. Ageing Res. Rev., v.10, n.4, p.430-9, 2011.

MARENGONI, A.; PASINA, L.; CONCOREGGI, C.; MARTINI, G. BROGNOLI, F.; NOBILI, A.; ONDER, G. ; BETTONI, D. Understanding adverse drug reactions in older adults through drug-drug interactions. Eur. J. Intern. Med., v.25, n.9, p.843-6, 2014.

MARUSIC, S.; BACIC-VRCA, V.; OBRELI NETO, P.R.; FRANIC, M.; ERDELJIC, V. GOJO-TOMIC, N. Actual drug-drug interactions in elderly patients discharged from internal medicine clinic: a prospective observational study. Eur. J. Clin. Pharm.., v.69, n.9, p.1717-24, 2013. 
MASSEL, D.R.; LITTLE, S.H. Antiplatelet and anticoagulation for patients with prosthetic heart valves. Cochrane Datab. Syst. Rev., v.7, CD003464. 2013.

MICROMEDEX. Greenwood Village, 2014. Disponível em: http://micromedex.com/. Acesso em: mar.-nov. 2006.

NYBORG, G.; STRAAND, J.; BREKKE, M. Inappropriate prescribing for the elderly--a modern epidemic? Eur. J. Clin. Pharm.., v.68, n.7, p.1085-94, 2012.

OBRELI NETO, P.R.; NOBILI, A.; DE LYRA, D.P.; PILGER, D.; GUIDONI, C.M.; DE OLIVEIRA BALDONI, A.; CRUCIOL-SOUZA, J.M.; CARVALHO FREITAS, A.L.; TETTAMANTI, M.; GAETI, W.P.; NAKAMURA CUMAN, R.K. Incidence and predictors of adverse drug reactions caused by drug-drug interactions in elderly outpatients: a prospective cohort study. J. Pharm. Pharm.. Sci., v.15, n.2, p.332-43, 2012.

OLIVEIRA MARTINS de, S.; SOARES, M.A.; FOPPE VAN MIL, J.W.; CABRITA, J. Inappropriate drug use by Portuguese elderly outpatients--effect of the Beers criteria update. Pharm. W. Sci., v.28, n.5, p.296-301, 2006.

ORGANIZAÇÃO MUNDIAL DA SAÚDE. OMS. Envelhecimento ativo: uma política de saúde. 1. ed. Brasília: Organização Pan-Americana da Saúde, 2005. NO. DE PÁGINAS

PASINA, L.; DJADE, C.D.; NOBILI, A.; TETTAMANTI, M.; FRANCHI, C.; SALERNO, F.; CORRAO, S.; MARENGONI, A.; IORIO, A.; MARCUCCI, M.; MANNUCCI, P. Drug-drug interactions in a cohort of hospitalized elderly patients. Pharmacoepidemiol.. Drug Saf., v.22, n.10, p.1054-60, 2013.

PASSARELLI, M. C. G.; JACOB-FILHO, W.; FIGUERAS, A. Adverse drug reactions in an elderly hospitalized population: inappropriate prescription is a leading cause. Drugs \& Aging, v.22, n.9, p.767-77, 2005.

PILOTTO, A.; FRANCESCHI, M.; MAGGI, S.; ADDANTE, F.; SANCARLO, D. Optimal management of peptic ulcer disease in the elderly. Drugs \& Aging, v.27, n.7, p.545-58, 2010 .
PIRMOHAMED, M.; JAMES, S.; MEAKIN, S.; GREEN, C.; SCOTT, A.K.; WALLEY, T.J.; FARRAR, K.; PARK, B.K.; BRECKENRIDGE, A.M. Adverse drug reactions as cause of admission to hospital: prospective analysis of 18820 patients. Brit. Med. J.: BMJ, v.329, n.7456, p.15-9, 2004.

SECOLI, S.-R.; FIGUERAS, A.; LEBRÃO, M.L.; DE LIMA, F.D.; SANTOS, J.L.F. Risk of potential drug-drug interactions among Brazilian elderly: a population-based, cross-sectional study. Drugs \& Aging, v.27, n.9, p.759-70, 2010 .

SICHIERI, K.; RODRIGUES, A. R.B.; TAKAHASHI, J.A.; SECOLI, S.R.; NOBRE, M.R.C.; MÓNICA, M.A.; JULIO, F.G. Mortality associated with the use of inappropriate drugs according beers criteria: a systematic review. Adv. Pharm. Pharm., v.1, n.2, p.74-84, 2013.

SMITH, L.; MCGOWAN, L.; MOSS-BARCLAY, C.; WHEATER, J.; KNASS, D.; CHRYSTYN, H. An investigation of hospital generated pharmaceutical care when patients are discharged home from hospital. Brit. J. Clin. Pharm.., v.44, n.2, p.163-5, 1997.

THOMSON, A.B.R.; SAUVE, M.D.; KASSAM, N.; KAMITAKAHARA, H. Safety of the long-term use of proton pump inhibitors. W. J. Gastroent., v.16, n.19, p.232330, 2010.

VONBACH, P.; DUBIED, A.; KRÄHENBÜHL, S.; BEER, JH. Prevalence of drug-drug interactions at hospital entry and during hospital stay of patients in internal medicine. Eur. J. Intern. Med., v.19, n.6, p.413-20, 2008.

WAHAB, M.S.A. The relevance of educating doctors, pharmacists and older patients about potentially inappropriate medications. Int. J. Clin. Pharm., v.37, n.6, p.971, 2015.

Received for publication on $22^{\text {th }}$ June 2015 Accepted for publication on $02^{\text {nd }}$ September 2016 
